\title{
MEMUTUS LOGIKA KARITATIF DALAM PRAKTIK PARIWISATA DI UBUD BALI
}

\author{
I Made Kusuma Negara, I Made Adikampana, dan Saptono Nugroho \\ Fakultas Pariwisata Universitas Udayana \\ Email:kusuma.negara@unud.ac.id
}

\begin{abstract}
Many villas in Ubud is located around agricultural land owned by farmers who are members of Subak. There is a deal that the villas are required to provide material contributions to local institutions, including Subak. Such contributions produce caritative framework which not in line towards the sustainability of tourism development. This paper addresses to offer the guidelines of sustainable tourism practice in Ubud, Bali. To fulfill this purpose, data has been collected from observations and interviews with selected informants and then analyzed descriptively. The analysis indicated that there is dualism perspective against agriculture, which has implications towards exclusivity in-group, especially farmers and villas. Each group attempts to maintain the dualism perspective by applying various tactics, which can lead to disharmonies relations between groups. It requires social guidance in order to reduce caritative framework by creating common tourism sphere through agrotourism.
\end{abstract}

Keywords: Agrotourism; Caritative; Farmer; Ubud; Villa.

\begin{abstract}
ABSTRAK
Banyak vila di Ubud memilih lokasi di sekitar areal pertanian milik petani yang tergabung dalam institusi Subak. Terdapat kesepakatan bahwa vila wajib memberikan bantuan atau sumbangan material ke institusi setempat, termasuk Subak. Kesepakatan menyumbang-disumbang dalam praktik pariwisata tersebut telah melahirkan logika karitatif dan jauh dari konteks keberlanjutan pembangunan pariwisata. Tulisan ini ditujukan untuk memberikan arahan bagi keberlanjutan praktik pariwisata di Ubud, Bali melalui pemutusan logika karitatif tersebut. Kebutuhan data untuk mencapai tujuan dengan observasi dan wawancara yang kemudian dibahas secara deskriptif. Hasil pembahasan menunjukkan bahwa terdapat dualisme cara pandang terhadap pertanian yang berimplikasi pada aktivitas eksklusif kelompok, khususnya petani maupun vila. Setiap kelompok berupaya untuk mempertahankan eksistensi dualisme tersebut dengan menerapkan berbagai siasat, yang dapat berujung pada tata relasi konfliktual. Untuk itu dibutuhkan panduan sosial guna memutus mata rantai logika karitatif dengan membangun ranah pariwisata bersama antara petani dengan vila melalui wisata Subak atau agrowisata.
\end{abstract}

Kata Kunci: Agrowisata; Karitatif; Petani; Ubud; Vila. 


\section{PENGANTAR}

Pariwisata dikembangkan sebagai salah satu strategi untuk meningkatkan kualitas hidup masyarakat (Andereck dan Nyaupane, 2011). Hal tersebut disebabkan pariwisata merupakan industri yang mampu menciptakan berbagai pengaruh atau manfaat bagi masyarakat (Okazaki, 2008). Ketika pariwisata mulai dikembangkan, pertimbangan pertama yang menjadi fokus adalah memastikan bahwa pariwisata dapat membangkitkan dan memberikan manfaat sebesar-besarnya bagi masyarakat di sekitarnya atau disebut dengan masyarakat lokal. Manfaat pariwisata bagi masyarakat lokal selanjutnya akan menumbuhkan penerimaan, dukungan, dan partisipasi masyarakat tersebut terhadap pariwisata. Dalam penelitiannya, Timothy (1999) serta Timothy dan Tosun (2003) menyebutkan bahwa partisipasi masyarakat lokal dalam pariwisata dapat dilakukan dengan dua cara, yakni partisipasi dalam pengambilan keputusan dan partisipasi dalam berbagi manfaat pariwisata. Adanya partisipasi masyarakat lokal dalam pengembangan pariwisata menurut Simpson (2009) dan Matarrita-Cascante $d k k .$, (2010) merupakan modal keberlanjutan pariwisata. Masyarakat lokal adalah komponen penting produk pariwisata di suatu destinasi (Inskeep, 1991). Mengintegrasikan masyarakat lokal dalam pengembangan pariwisata menjadi prasyarat mutlak keberlanjutan pariwisata. Integrasi tersebut dapat tercipta bila pariwisata dapat memberikan berbagai manfaat, baik sosial budaya, lingkungan, maupun ekonomi bagi masyarakat lokal. Selain itu, keberlanjutan pariwisata akan tercipta apabila mampu secara simultan memenuhi berbagai kebutuhan, termasuk kebutuhan masyarakat lokal (Liu, 2003). Sering kali penyebab munculnya permasalahan dalam pengembangan pariwisata karena terabaikannya kepentingan masyarakat tersebut. Masyarakat lokal akan membenarkan berbagai cara untuk memenuhi kebutuhannya, meskipun cenderung kontra produktif dengan keberlanjutan pengembangan suatu daerah tujuan pariwisata atau destinasi pariwisata.
Permasalahan keberlanjutan pariwisata juga muncul di Ubud, Bali. Ubud merupakan salah satu kawasan pariwisata dengan keunikan atraksi berbasis budaya masyarakat lokal (living culture). Kawasan pariwisata Ubud mempunyai posisi strategis dalam kepariwisataan Bali karena tingkat kunjungannya yang relatif tinggi dibandingkan dengan destinasi pariwisata lainnya. Ini dibuktikan dengan masuknya Ubud sebagai satu-satunya destinasi pariwisata di Bali dalam 10 besar destinasi pariwisata terfavorit di Asia versi penghargaan Travellers's Choice Destinations tripAdvisor (Hanifah, 2014). Tingginya kunjungan ke Ubud berakibat pada peningkatan penyediaan amenitas pariwisata, terutama fasilitas akomodasi. Fasilitas ini merupakan tempat tinggal sementara wisatawan selama berada di destinasi pariwisata. Salah satu jenis akomodasi yang banyak dikembangkan adalah vila. Mayoritas vila di kawasan pariwisata Ubud memilih lokasi di wilayah perdesaan, terutama di sekitar areal pertanian milik para petani sebagai anggota atau krama Subak. Adanya vila ini tentu saja dapat memberikan pengaruh khususnya bagi krama Subak tersebut. Akan tetapi, pengembangan vila di sekitar areal pertanian belum mampu memberikan manfaat atau kontribusi yang berarti. Ini ditunjukan dengan munculnya resistensi krama Subak terhadap keberadaan vila. Krama Subak melakukan pembenaran terhadap berbagai aktivitasnya demi mendapatkan kontribusi dari keberadaan vila yang kurang memperhatikan keberlanjutan pengembangan pariwisata. Bentuk pembenaran tersebut di antaranya membangun kandang penggemukan sapi di sekitar vila dengan maksud untuk memberikan ketidaknyamanan bagi penghuni vila dan menghalangi pandang (view) vila ke areal pertanian dengan menanam tanaman penyakat.

Siasat perlawanan berupa pembenaran yang ditunjukkan krama Subak kemudian menghasilkan kesepakatan berupa pemberian bantuan atau sumbangan material oleh vila ke institusi Subak. Insentif material tersebut sebagian besar dihabiskan untuk ritual keagamaan yang terkait dengan kegiatan 
pertanian. Kesepakatan menyumbang-disumbang inilah yang melahirkan logika karitatif dan jauh dari konteks keberlanjutan pariwisata. Ironisnya, logika ini selanjutnya menjadi basis kesadaran setiap pelaku yaitu krama Subak dan manajemen vila termasuk pula masyarakat sekitar vila lainnya dalam pengembangan pariwisata di kawasan pariwisata Ubud. Berdasarkan fenomena tersebut, tulisan ini ditujukan untuk merubah siasat krama Subak dan manajemen vila menjadi strategi yang mampu memutus mata rantai logika karitatif demi keberlanjutan praktik pariwisata di kawasan pariwisata Ubud.

Tulisan tentang memutus logika karitatif dalam praktik pariwisata di kawasan pariwisata Ubud ini menggunakan pendekatan kualitatif. Pendekatan ini merupakan cara untuk mengungkap fenomena secara lebih mendalam berdasarkan pengalaman dan pandangan masyarakat lokal dan manajemen vila. Teknik pengumpulan data melalui observasi dan wawancara. Wawancara dilakukan terhadap informan terpilih karena pengetahuan dan ketokohannya. Keseluruhan informan berjumlah sembilan orang yang terdiri dari unsur petani atau krama Subak, pemimpin Subak atau pekaseh, pemimpin desa adat/desa pakraman dan desa dinas serta manajemen vila. Informasi yang digali terkait dengan perspektif masing-masing informan terutama petani dan manajemen vila terhadap pertanian serta hubungan yang selama ini terjalin antara masyarakat lokal khususnya petani dengan manajemen vila. Informasi yang terkumpul selanjutnya ditafsirkan dan disajikan dengan sebenarnya secara deskriptif untuk memenuhi tujuan dalam tulisan ini, yaitu memberikan arahan keberlanjutan praktik pariwisata di Ubud, Bali.

\section{PEMBAHASAN \\ Rekonstruksi Pariwisata Berbasis Pertanian}

Ubud merupakan kawasan pariwisata yang menawarkan kehidupan masyarakat perdesaan Bali yang memiliki budaya agraris religius. Dengan basis atraksi tersebut, dapat dinyatakan bahwa tren pengembangan produk pariwisata Ubud termasuk komponen akomodasi lebih mengarah ke wilayah pedesaan. Saat ini jenis akomodasi yang banyak dikembangkan berupa vila yang berlokasi di sekitar areal pertanian milik masyarakat lokal. Salah satu area pengembangan vila di kawasan pariwisata Ubud teramati di Lodtunduh. Lodtunduh merupakan desa di dalam kawasan pariwisata Ubud (Peraturan Daerah Kabupaten Gianyar Nomor 16 Tahun 2012) yang mayoritas masyarakatnya bekerja di sektor pertanian dengan menggarap persawahan dan tegalan. Pengelolaan pertanian masyarakat Lodtunduh didasarkan atas sistem Subak. Yang menarik kemudian tampak di Lodtunduh adalah pola pembangunan vila yang mengelilingi areal pertanian krama Subak. Dapat dikatakan bahwa manajemen vila secara sadar telah memanfaatkan aktivitas pertanian tersebut sebagai faktor penarik (pull factor) agar wisatawan datang berkunjung dan tinggal lebih lama lagi di vila.

Terkait dengan tujuan penulisan tentang memutus logika karitatif guna memastikan keberlanjutan praktik pariwisata di kawasan pariwisata Ubud, diperlukan kajian terhadap ranah pariwisata yang digunakan sebagai dasar strukturasinya sehingga pada tulisan ini terdapat dua pembahasan yaitu tentang ranah dan strukturasi pariwisata. Pembahasan mengenai ranah pariwisata bermanfaat untuk mengidentifikasi pelaku pariwisata, modal yang diperjuangkan, dan jenis kesadaran yang dimiliki setiap pelaku pariwisata. Setelah semua teridentifikasi, kemudian menstrukturasi pariwisata berbasis pertanian. Strukturasi dibutuhkan untuk memproduksi struktur yang berupa kesepakatan bersama para pelaku tentang aturan (rules) dalam suatu sistem pariwisata. Aturan yang disepakati merupakan representasi kepentingan bersama dengan tujuan untuk membangun praktik pariwisata konstruktif dan produktif di kawasan pariwisata Ubud dan khususnya di Lodtunduh.

Gagasan tentang ranah dan strukturasi dalam mengkaji fenomena pariwisata yang berkembang di Lodtunduh didasarkan atas pemikiran Pierre Bourdieu dan Anthony 
Giddens. Keduanya mempromosikan cara pandang baru dalam menafsirkan fenomena sosial yang sebelumnya didominasi oleh perspektif dualisme. Perspektif dualisme adalah cara pandang yang terbagi menjadi dua paradigma berpikir yakni naturalistispositivistis dan humanistis-interpretatif (Poloma, 2003). Masing-masing cara pandang tersebut bersikukuh bahwa pemikirannya tersebut yang benar, sedangkan lainnya salah. Menyikapi cara pandang demikian, Bourdieu dan Giddens berupaya untuk memberikan alternatif terhadap dominasi perspektif dualisme melalui istilah yang disebut dengan perspektif dualitas. Bagi keduanya, perspektif dualisme sudah tidak memadai dalam membahas realitas sosial masyarakat kontemporer yang sedemikian kompleksnya. Objek kajian tentang masyarakat bukanlah individu atau struktur, tetapi lebih pada proses berpadunya individu dan struktur yang akhirnya menghasilkan suatu praktik sosial. Jadi dapat dikatakan bahwa praktik sosial inilah yang menjadi fokus kajian tentang fenomena sosial karena dari praktik sosial akan dapat diketahui realitas sosial yang terjadi. Dengan mengkaji praktik sosial tersebut, Bourdieu melahirkan teori strukturalisme genetis, sedangkan Giddens memperkenalkan teori strukturasi.

Cara pandang dualitas ini dinilai lebih memadai guna mengkaji fenomena pariwisata Lodtunduh, yang kompleksitasnya akan diurai dengan kedua teori tersebut. Teori strukturalisme genetis diperlukan untuk mengidentifikasi ranah pariwisata dalam ruang sosial Lodtunduh. Sedangkan teori strukturasi digunakan untuk penentuan strategi pariwisata berbasis pertanian dalam rangka memutus kerangka logika karitatif. Pariwisata berbasis pertanian ini disebut rekonstruksi mengingat di Lodtunduh saat ini telah berlangsung praktik pariwisata yang menunjukan adanya permasalahan antara krama Subak dengan manajemen vila.

Dalam mengidentifikasi kondisi pariwisata Lodtunduh saat ini, digunakan teori strukturalisme genetis Bourdieu dengan persamaan sebagai berikut :
$($ Habitus $\times$ Modal $)+$ Ranah $=$ Praktik

Beberapa konsep dalam persamaan (1) berguna untuk mengidentifikasi praktik pariwisata Lodtunduh. Selain itu, bahasan Bourdieu lainnya mengenai ruang sosial dan doxa juga digunakan pada pembahasan ini.

Praktik atau tindakan yang disebut dalam rumusan generatif tersebut merupakan produk dari hubungan atau relasi antara habitus dan ranah dan keduanya merupakan produk sejarah (Fashri, 2014). Secara sederhana, habitus dapat disebut dengan kebiasaankebiasaan. Habitus mengacu pada sekumpulan disposisi yang tercipta dan terformulasi melalui kombinasi struktur objektif dan sejarah personal. Disposisi diperoleh dari berbagai posisi sosial yang berada di dalam suatu ranah dan mengimplikasikan suatu penyesuaian subjektif terhadap posisi tersebut (Mahar dkk., 2005). Ranah merupakan arena kekuatan yang didalamnya terdapat upaya untuk mendapatkan modal atau sumber daya dan juga demi memperoleh akses tertentu yang dekat dengan hirarki kekuasaan. Ranah mengandaikan beragam potensi yang dimiliki oleh individu atau kelompok dalam posisinya masing-masing (Fashri, 2014). Konsep ranah tidak bisa dilepaskan dari ruang sosial yang mengacu pada keseluruhan konsepsi tentang dunia sosial. Konsep ini memandang realitas sosial sebagai suatu topologi (ruang). Dapat dikatakan bahwa ruang sosial mencakup banyak ranah di dalamnya yang memiliki keterkaitan satu sama lain (Fashri, 2014). Dalam ranah terdapat pertaruhan dan kekuatan individu atau kelompok melalui kepemilikian modal dengan komposisi yang bervariasi. Modal dapat dikatakan sebagai sebuah konsentrasi kekuatan spesifik yang beroperasi dalam ranah (Fashri, 2014). Modal berperan sebagai relasi sosial yang terdapat di dalam suatu sistem pertukaran (Mahar dkk., 2005). Dengan demikian modal dapat dipertukarkan dan dapat menentukan posisi dan status individu atau kelompok dalam ranah dan ruang sosial (Fashri, 2014). Terdapat empat macam modal, yaitu modal budaya, modal sosial, modal ekonomi, dan modal simbolik. 
Modal budaya merupakan pengetahuan, kode-kode budaya, etika, yang berperan dalam penentuan dan reproduksi kedudukan sosial. Sementara modal sosial didefinisikan sebagai jaringan yang merupakan sumber daya dalam membangun hubungan sosial. Modal ekonomi bersumber dari kepemilikan material yang dapat dengan mudah digunakan dengan segala tujuan serta diwariskan dari satu generasi ke generasi berikutnya. Sedangkan modal simbolik tidak terlepas dari kekuasaan simbolik berupa prestis, status, otoritas, dan legitimasi.

Konsep penting lainnya dari Bourdieu adalah doxa. Konsep ini berawal dari konsep dominasi simbolik berupa suatu penindasan dengan memakai simbol-simbol tertentu. Penindasan beroperasi secara halus, tidak terasakan, tetapi sebagai sesuatu yang perlu dilakukan secara formal. Dapat dikatakan bahwa penindasan tersebut mendapat persetujuan dari pihak yang ditindas itu sendiri. Mekanisme dominasi simbolik bermuara pada pemikiran tentang doxa, yaitu mengenai pandangan penguasa yang dianggap sebagai pandangan seluruh masyarakat. Masyarakat kehilangan sikap kritisnya terhadap penguasa. Doxa merupakan siasat penguasa dalam meraih, mempertahankan, dan mengembangkan kekuasaannya.

\section{Perspektif krama Subak dan vila terhadap pertanian}

Terdapat perbedaan perspektif antara krama Subak dan pihak vila terhadap pertanian yang berlangsung selama ini di Lodtunduh. Hal ini tidak lepas dari adanya dualisme cara pandang terhadap pertanian tersebut. Krama Subak melakukan aktivitas pertanian dengan basis kesadaran atau habitus produksi pertanian dalam rangka memenuhi kebutuhan hidup. Sedangkan pihak vila menafsirkan lansekap pertanian beserta aktivitasnya sebagai bagian daya tarik vila. Dengan demikian terjadi penafsiran masing-masing terhadap pertanian di Lodtunduh yang berimplikasi pada aktivitas eksklusif kelompok, baik krama Subak maupun pihak vila. Krama Subak eksklusif melakukan proses pertanian, dari pra-produksi sampai pasca-produksi. Sedangkan pihak vila menafsir pertanian sebagai daya tarik sehingga memberikan nilai tambah bagi keberadaan usahanya.

Dapat disebutkan bahwa Lodtunduh sebagai suatu ruang sosial telah ditafsirkan berbeda-beda sesuai dengan ranahnya masing-masing. Krama Subak dengan ranah pertaniannya dan pihak vila dengan ranah pariwisatanya. Dualisme ini menciptakan hubungan atau relasi disharmonis di antara krama Subak dan pihak vila. Ini menunjukkan belum ada perspektif yang sama dan bersama dalam memandang dan memahami aktivitas pertanian sebagai basis atraksi pariwisata. Dengan kata lain, belum tercipta ranah pariwisata bersama, yang dalam tulisan ini disebut dengan agrowisata.

Meskipun dalam praktik pariwisatanya, vila telah memanfaatkan aktivitas pertanian sebagai faktor penarik wisatawan, akan tetapi habitusnya belum dapat memenuhi perspektif agrowisata. Perspektif agrowisata dapat dijelaskan sebagai familiarisasi wisatawan terhadap aktivitas pertanian dengan terlibat langsung di dalamnya untuk mendapatkan pengalaman (Marques, 2006). Wisatawan yang menginap selama ini bersikap pasif, hanya menikmati suasana aktivitas pertanian yang tampak sangat jelas dari vila. Selain itu wisatawan tidak difasilitasi untuk berinteraksi secara aktif dengan krama Subak serta mendapatkan pengalaman proses pertanian secara langsung. Pada konteks ini wisatawan yang menginap di vila dapat dikatagorikan sebagai tamu. Terlebih lagi, perilaku pihak vila yang terkadang membuang sampah ke saluran irigasi Subak. Keadaan ini menunjukkan cara pandang pihak vila yang tidak memasukan aktivitas pertanian sebagai aset pariwisata yang wajib dijaga keberlanjutannya.

Dari pihak krama Subak, keberadaan vila justru dianggap sebagai "pengganggu" karena areal pertanian menjadi tercemari sampah dan aktivitas pertanian menjadi tontonan gratis bagi tamu vila. Akan tetapi, krama Subak terpaksa harus melakukan aktivitas pertaniannya karena merupakan cara produksinya dalam rangka melangsungkan hidup. Belum ada 
kesadaran bahwa areal pertanian beserta aktivitasnya merupakan modal atau sumber daya pariwisata berbasis pertanian yang dapat dikembangkan sebagai alternatif produk yang bernilai selain produksi pertanian.

\section{Siasat vila dan krama Subak dalam mempertahankan eksistensi dualisme}

Temuan berikut menunjukkan adanya upaya yang dilakukan baik oleh krama Subak maupun pihak vila yang berakibat pada eksisnya dualisme cara pandang dalam ruang sosial Lodtunduh. Perbedaan tersebut jika tidak dikelola baik akan dapat melahirkan tata relasi konfliktual. Walaupun suasana disharmoni ini belum tereksplisitasi menjadi konflik terbuka, tetapi dibiarkan terus-menerus bukan tidak mungkin akan menjadi masalah dalam keberlanjutan pengembangan pariwisata dan menyebabkan biaya mahal secara ekonomi dan sosial. Biaya ekonomi yang harus ditanggung akan timbul karena kerusakan-kerusakan material, sedangkan biaya sosial terkait dengan disintegrasinya masyarakat lokal di Lodtunduh.

\section{Siasat Pihak Vila}

Dalam mempertahankan eksistensinya, pihak vila melakukan beberapa upaya di antaranya:

a. Siasat sosial budaya

Pihak vila memanfaatkan jaringan sosial dan budaya yang ada di Lodtunduh. Pada konteks sosial, pihak vila membangun tata relasi patron-client dengan melakukan rekruitmen karyawan vila dari masyarakat lokal, dengan prioritas pemilik tanah yang mengontrakkan lahannya kepada pihak vila. Langkah ini ditopang dengan siasat budaya yang dilakukan, yaitu dengan upaya merekrut pengurus banjar dinas di mana vila tersebut beroperasi sebagai tenaga pengamanan. Modus ini juga diketahui oleh pengurus banjar adat, sehingga pola rekrutmen karyawan seperti ini mengandung dua dimensi sekaligus, yaitu secara sosial merengkuh tenaga kerja terutama dari masyarakat lokal dan secara budaya menggunakan relasi budaya berupa banjar (kelompok masyarakat lokal Bali yang merupakan bagian desa dinas atau desa adat). Pemanfaatan jaringan berbasis sosial budaya oleh pihak vila akan memapankan pola relasi patronasi dengan bias pemahaman bahwa modal ekonomi merupakan modal utama dan pemiliknya akan selalu berada pada posisi sosial strategis. Dengan siasat ini, vila mendapatkan dua keuntungan sekaligus berupa keamanan menjalankan usaha akomodasinya dan memiliki wakil dalam memenuhi undangan di banjar dinas maupun banjar adat.

b. Siasat ekonomi

Siasat ini dilakukan pihak vila untuk menjaga posisi sosial yang lebih tinggi terhadap masyarakat lokal. Dengan kata lain guna makin mengukuhkan tata relasi patron-client. Upaya yang dilakukan pihak vila adalah dengan memberi bantuan atau sumbangan ke banjar dinas, banjar adat, dan juga Subak. Status sebagai pemberi tersebut menjadikan pihak vila berkedudukan lebih tinggi yakni sebagai patron. Praktik menyumbang-disumbang inilah yang melahirkan logika karitatif dalam penyelenggaraan pariwisata Lodtunduh. Logika ini menjadi basis kesadaran pihak vila dalam praktik pariwisata, yang dihasilkan dari ketidakmampuan masyarakat lokal (peminta sumbangan) dalam mengenali posisi sesungguhnya pada penyelenggaraan pariwisata Lodtunduh. Hal ini tampak pula dari tata relasi patron-client yang terbangun, ketika posisi pengontrak tanah yaitu pihak vila menjadi lebih tinggi dan justru pihak pemilik tanah yang terkesan meminta pekerjaan. Fenomena menarik terjadi ketika sudah ada vila yang melakukan perpanjangan kontrak dengan masyarakat lokal pemilik tanah. Ini menunjukkan selama vila beroperasi dalam waktu relatif lama, kedua belah pihak merasa nyaman dengan pola relasi patronasi tersebut. Hal ini berakibat kepada eksistensi doxa (kesadaran semu) patronasi berbasis modal ekonomi yang dimiliki pihak vila. 
Munculnya kesadaran semu akan semakin memapankan logika karitatif dalam bentuk menyumbang-disumbang.

c. Siasat politik

Siasat politik ditujukan untuk mendapatkan sokongan guna keberlangsungan usahanya. Pendekatan yang dilakukan pihak vila kepada institusi maupun tokoh-tokoh penting di Lodtunduh guna memperoleh restu dan dukungan dalam penyelenggaraan bisnis akomodasi ini. Kondisi ini menjadikan masyarakat lokal segan jika melakukan konflik terbuka dengan vila. Hasil identifikasi menunjukkan bahwa institusi utama penopang pola patronasi vila ternyata adalah banjar dinas dan banjar adat dimana vila-vila berlokasi. Fenomena ini dapat dipahami karena institusi banjar adalah penguasa wilayah tempat beroperasinya vila-vila tersebut. Ini menunjukkan bahwa intensifikasi patronasi dengan logika karitatif berada dalam banjar. Banjar adalah ranah di mana tempat pertukaran modal berlangsung secara intensif dengan doxa bahwa modal ekonomi merupakan modal dominan. Pertanyaannya kemudian, di mana posisi institusi Subak beserta krama-nya? Dengan tata relasi yang demikian, sesungguhnya pihak yang paling dirugikan adalah para petani dengan institusi Subaknya. Subak paling lemah posisi sosialnya karena relatif tidak memiliki modal dalam ranah. Dapat dikatakan Subak teralienasi di tempatnya sendiri karena dianggap tidak penting dalam praktik penyelenggaraan pariwisata Lodtunduh. Bahkan Subak dianggap sebagai pihak yang mengganggu, karena beberapa aktivitas (siasat) krama Subak yang dapat mengurangi kenyamanan tamu vila.

Dapat disebutkan bahwa pihak vila yang berkoalisi dengan segelintir elit banjar dapat memaksimalisasi modal ekonominya untuk dipertukarkan dengan tiga jenis modal lainnya, yaitu modal budaya, sosial, dan simbolis.

1. Siasat krama Subak

Beberapa upaya yang dilakukan krama Subak, baik personal maupun secara institusional (melalui Subak), tidaklah secanggih yang dilakukan pihak vila. Hal ini dikarenakan ketidakmampuan krama Subak dalam mengidentifikasi modal yang dimiliki dalam penyelenggaraan pariwisata. Terlebih lagi, ranah pariwisata yang mewadahi kepentingan bersama di Lodtunduh memang belum terbentuk. Krama Subak melakukan siasat perlawanan secara sporadis, tradisional, dan cenderung tidak langsung. Perlawana krama Subak merupakan bentuk ekspresi kekecewaan guna mendapatkan perhatian lebih dari pihak vila. Beberapa bentuk perlawanan krama Subak tergambarkan dalam beberapa aktivitas seperti membangun kandang penggemukan sapi di sekitar vila dengan maksud untuk memberikan ketidaknyamanan bagi penghuni vila, menghalangi pandangan vila ke areal persawahan dengan menanam pakan sapi, pandan harum, dan pohon pisang, dan cara mengusir burung dengan suara-suara tertentu yang dirasakan dapat mengganggu istirahat tamu vila.

Motivasi dilakukan aktivitas tersebut adalah untuk menciptakan kondisi yang kurang kondusif bagi kenyamanan tamu vila. Siasat yang dijalankan krama Subak tersebut malah justru semakin memperlemah posisinya dalam ranah. Terjadi apa yang disebut dengan blaming the victim (menyalahkan korban). Hal ini disebabkan karena adanya pihak yaitu banjar yang memiliki modal simbolis, sehingga memiliki kuasa untuk menilai dalam ranah. Jenis modal ini sangat penting karena dengan kuasanya untuk menafsir kebenaran akan menjadikan pihak yang memilikinya akan sangat dominan posisi sosialnya. Ketidakmampuan krama Subak dalam mengidentifikasi jenis modal yang dimiliki karena adanya doxa yang dimapankan oleh koalisi vila dan elit banjar sehingga diperlukan jenis kesadaran baru dalam mindset petani, yaitu dari pemikiran praktis menuju reflektif. 


\section{Dari Siasat Menuju Strategi: Memutus Logika Karitatif dalam Pariwisata}

Praktik-praktik kontra produktif yang telah disebutkan sebelumnya dipengaruhi oleh perspektif dualisme. Perspektif ini memberikan pondasi pada tafsir masing-masing tehadap pertanian, sehingga membatasi potensi krama Subak berpartisipasi dalam penyelenggaraan pariwisata Lodtunduh. Praktik meminta dan memberi sumbangan disebabkan oleh adanya logika karitatif pada pola pikir para pihak yang berkepentingan di Lodtunduh. Praktik yang berdasar logika karitatif sangat jamak terjadi saat ini di kawasan pariwisata Ubud bahkan Bali. Masyarakat lokal sejatinya adalah pemilik ruang dengan segala modal di dalamnya, malah berada dalam posisi meminta-minta dalam ruangnya sendiri.

Fenomena tersebut disebabkan oleh ketidakmampuan masyarakat lokal dalam menemukan dan mengenali modal atau sumber daya pariwisata yang dimiliki. Guna memampukan masyarakat lokal dalam mengidentifikasi modal atau sumber daya tersebut, hal yang penting dilakukan adalah menciptakan ranah pariwisata. Untuk kasus Lodtunduh, telah disebutkan sebelumnya bahwa ranah pariwisata yang ideal adalah berbasis pertanian atau memenuhi perspektif agrowisata. Penciptaan ranah menjadi penting untuk memfasilitasi berbagai pihak yang berkepentingan atau aktor pariwisata dengan komposisi modal yang dimilikinya agar saling bertukar dan menguatkan. Pada konteks saling menguatkan, diperlukan kelembagaan agrowisata yang mengatur mekanisme pertukaran modal secara adil dan wajar. Kelembagaan yang dimaksud bertujuan agar tercipta sinergitas antaraktor pariwisata, bukan justru menyediakan ruang konflik baru.

Berdasarkan teori strukturalisme genetis Bourdieu, pariwisata yang direncanakan dan dikembangkan di Lodtunduh akan memenuhi rumusan generatif sebagai berikut :

(Habitus pariwisata $\times$ Modal) + Ranah agrowisata $=$ Praktik pariwisata berbasis pertanian Lodtunduh ......(2)
Persamaan (2) merupakan basis perencanaan agrowisata Lodtunduh yang berfungsi sebagai panduan rekayasa sosial guna memutus mata rantai logika karitatif beserta bentuk praktiknya yang marak terjadi. Nilai strategis aplikasi rumusan di atas akan teridentifikasi jenis modal setiap pihak yang berhimpun dalam ranah agrowisata. Dengan masuknya pihak petani sebagai aktor dalam ranah agrowisata yang dikembangkan bersama dengan pihak vila, dapat merubah pola siasat menjadi strategi. Siasat dilakukan secara personal atau kelompok eksklusif. Dasarnya adalah skeptis atau rasa curiga antar individu atau kelompok. Keberhasilan menjalankan siasat dalam rangka melemahkan eksistensi personal atau kelompok lainnya. Sedangkan strategi merupakan upaya yang dilakukan secara kolektif untuk mencapai tujuan bersama. Strategi didasarkan atas sinergitas dalam rangka produktivitas.

\section{SIMPULAN}

Perspektif dualisme terjadi karena belum terbangunnya ranah pariwisata kolektif yang merupakan ruang bagi pertukaran modal di antara aktor atau stakeholder pariwisata di Lodtunduh. Belum terbangun strategi bersama, yang muncul hanyalah saling siasat untuk mempertahankan eksistensinya masingmasing. Terbangunnya pariwisata berbasis pertanian atau wisata Subak di Lodtunduh sebagai kerangka berpikir dan bertindak para aktor, menjadi prasyarat dari praktik keberlanjutan pariwisata. Hal ini akan memampukan setiap pihak yang terlibat untuk saling bekerja sama, melakukan simbiosis mutalisme, dan bertukar modal secara adil dan wajar (fair). Praktik pariwisata berbasis pertanian di Lodtunduh akan mengumpulkan para aktor pada ranah spesifik, yaitu ranah agrowisata. Dalam konteks inilah, posisi institusi Subak menjadi strategis karena akan menjadi tumpuan bagi pengembangan pariwisata pertanian. Strategis karena dalam praktik pertanian Subak telah memiliki habitus khas. Hal ini merupakan hasil dari praktik yang dilakukan secara terusmenerus, berulang, dan berpola sehingga krama Subak sudah sangat hapal dengan 
berbagai dinamika pertanian yang digeluti secara intensif tersebut. Di sisi lainnya, pihak vila yang selama ini telah menjalankan roda bisnis akomodasi, memiliki pemahaman dalam mengkreasi produk pariwisata dan melayani wisatawan, sehingga memiliki habitus yang khas pula.

Arti penting praktik agrowisata adalah mempertemukan dua habitus yakni Subak dan vila. Pada awal pertemuan, kemungkinan akan terjadi cultural shock, sehingga diperlukan kesadaran reflektif guna menyesuaikan dengan perubahan sosial yang terjadi. Perubahan ini mendorong para aktor untuk beranjak dari kesadaran praktis, yang merupakan kesadaran dalam menjalankan rutinitas keseharian sehingga tindakannya seolah otomatis, menuju kesadaran reflektif. Dapat disebutkan bahwa kesadaran praktis digunakan ketika realitas sosial berjalan seperti biasa atau rutin, sedangkan kesadaran reflektif timbul ketika terjadi derutinisasi di tingkatan praktik keseharian masyarakat lokal. Praktik menyumbang-disumbang yang berpijak pada logika karitatif akan diderutinisasi dalam rekonstruksi praktik agrowisata di Lodtunduh karena hanya menguntungkan segelintir pihak. Terlebih lagi, para petani beserta institusi Subak menjadi pihak yang tidak mendapatkan keuntungan berarti karena belum dioptimalkannya modal yang dimilikinya. Akan didekonstruksi jaringan para aktor yang selama ini memapankan keuntungan bagi diri dan kelompoknya semata karena praktik menyumbang-disumbang dalam logika karitatif, menjadi praktik pertukaran modal secara adil dan wajar dalam logika kesetaraan. Optimalisasi modal yang dimiliki petani dalam institusi Subak dapat terjadi jika para aktor di ruang sosial Lodtunduh bersepakat untuk mengkreasi agrowisata, sehingga terjadi ekstensifikasi ranah pariwisata dari eksklusif vila menjadi inklusif Subak. Ini berarti posisi subak dalam ranah pariwisata beranjak dari marginal menuju sentral.

\section{DAFTAR PUSTAKA}

Andereck, K.L. dan G.P. Nyaupane. 2011. Exploring the Nature of Tourism and
Quality of Life Perceptions among Residents. Journal of Travel Research 50(3): 248-260.

Fashri, F. 2014. Pierre Bourdieu; Menyingkap Kuasa Simbol. Cetakan Pertama. Jalasutra. Yogyakarta.

Hanifah, M. 2014. Ubud Masuk 10 Besar Destinasi Wisata Terfavorit di Asia. http://www.travel.okezone.com. diakses tanggal 16 April 2014.

Inskeep, E. 1991. Tourism Planning : an integrated and sustainable development approach. Van Nostrand Reinhold, New York.

Liu, Z. 2003. Sustainable Tourism Development: A Critique. Journal of Sustainable Tourism 11(6): 459-475.

Mahar, C., R. Harker, dan C. Wilkes 2005. Posisi Teoretis Dasar. Dalam An Introduction to the Work of Pierre Bourdiue: The Practice Theory. Editor R. Harker, C. Mahar, dan C. Wilkes. Macmillan. London. Terjemahan Pipit Maizier. 2005. (Habitus x Modal) + Ranah $=$ Praktik $:$ Pengantar Paling Kompeherensif kepada Pemikiran Pierre Bourdieu. Cetakan Pertama. Jalasutra. Yogyakarta.

Marques, H. 2006. Searching for complementarities between agriculture and tourism-the demarcated wineproducing regions of northern Portugal. Tourism Economics 12(1): 147-155.

Matarrita-Cascante, D., M.A. Brennan, dan A.E. Luloff. 2010. Community agency and sustainable tourism development: the case of La Fortuna, Costa Rica. Journal of Sustainable Tourism 18(6): 735-756.

Okazaki, E. 2008. A Community-Based Tourism Model: Its Conception and Use. Journal of Sustainable Tourism 16(5): 511- 529. 
Poloma, M.M. 1979. Contemporary Sociological Theory. Macmillan. New York. Terjemahan Tim Penerjemah YASOGAMA. 2003. Sosiologi Kontemporer. Cetakan Kelima. PT RajaGrafindo Persada. Jakarta.

Simpson, M.C. 2009. An integrated approach to assess the impacts of tourism on community development and sustainable livelihoods. Community Development Journal 44(2): 186-208.
Timothy, D.J. 1999. Participatory Planning: A View of Tourism in Indonesia. Annals of Tourism Research 26(2): 371391.

Timothy, D.J. dan C. Tosun. 2003. Appropriate Planning for Tourism in Destination Communities: Participation, Incremental Growth and Collaboration. Dalam Tourism in Destination Communities. Editor S. Singh, D.J. Timothy, dan R.K. Dowling. CABI Publishing. Wallingford. 